\title{
Maxillary Sinus Cancer pTis TNM Finding v8
}

National Cancer Institute

\section{Source}

National Cancer Institute. Maxillary Sinus Cancer pT is TNM Finding v8. NCI Thesaurus. Code C133034.

Maxillary sinus cancer with a finding of carcinoma in situ. (from AJCC 8th Ed.) 